\title{
Critical Analysis of Contract Farming Practice in East Java - Indonesia
}

\author{
Kartika Dewi Sri Susilowati*, Nur Indah Riwajanti \\ Accounting Department \\ State Polytechnic of Malang \\ Malang, Indonesia \\ *kartika.dewi@polinema.ac.id
}

\author{
Asminah Rachmi \\ Business Administration Department \\ State Polytechnic of Malang \\ Malang, Indonesia
}

\begin{abstract}
This study explored the technical implementation of the contract farming partnership which had been done by farmers and their partner companies in East Java, and identifying issues and benefits of partnership for both parties This study employed an interpretive research design, following a post-positivist paradigm. The data were collected by means of indepth interviews, observation and document study and were analyzed using the key tenet of Martin Heidegger's interpretive phenomenology. The interpretive process was achieved through hermeneutic circle to understand how individuals involved in the program interpreted the program including their own experiences as well as their interactions with other parties. The results of the study show that the created contract farming partnership generally has positive effect on farmers in the form of increased income, access to market, access to credit and technology, increased ability to manage risk, employment opportunities for indirect family members, empowerment of women and development successful business culture. Nevertheless, it was also evidence that contractual farming has negative consequences for farmers, such as high dependency, under-age employment and cooptation of land use. The results from the study have direct relevance to policy makers in Indonesia, especially those that have been implemented contract farming and to agribusiness companies seeking contractual relationships for commodity production.
\end{abstract}

Keywords: contract farming, agricultural contract, partnership agricultural commodities

\section{INTRODUCTION}

Almost all development activities in Indonesia are always associated with partnerships, even with different patterns and approaches. The most common form of partnership in agriculture in Indonesia today is the contract farming model. Contract farming is an institutional mechanism (contract) that strengthens the bargaining position of farmers by linking directly or indirectly with business entities that are economically stronger [1]. In this contract, local farmers are asked to plant certain agricultural commodities and submit their production with the quantity and quality that have been determined in advance in exchange for inputs (e.g. credit, seeds, fertilizers, pesticides, technical services, etc.) that have been given upfront [2].

Proponents of contract farming promote this system as a 'dynamic partnership' between small farmers and a large business, which benefits both, without sacrificing others [3] Contract farming is also believed to be an instrument for technology transfer, creating economic political stability through income distribution, and most importantly supporting agriculture modernization [1]. However, it cannot be denied that many cases show that the implementation of contract farming failed to produce the results referred to above, because at the same time contract farming actually became a systematic way to marginalize farmers [4]. Through this system, farmers are faced with a business competition that is not balanced with the core business that is usually large-scale economies [5,6]. The imbalance of power between farmers and companies is seen as not benefiting farmers. This can be seen from the dominance of buyers in determining the price, quantity and quality of commodities produced, planting and harvesting schedules, technology used and so on without involving the participation of farmers [7].

Contract farming is one of the ways in production mechanism that can only be practiced if there are at least two parties who work together for a certain unit of time which is stipulated in a written or oral agreement. In this connection, each party uses the resources they control. The first party in the relationship can be a processing unit or marketing unit. The processing unit or marketer based on its ownership status can be a state company, a private company, or a joint venture between state and private or private and private, both foreign and domestic. This unit will then act as a core company. Whereas the second party is the farmers, who act as satellites. The resources controlled by the core company are capital, sometimes also the name / brand and market guarantees, while the resources controlled by farmers are generally land and labor. In some cases farmers only control the workforce.

Somewhat different from the usual buying and selling relationship, in contract farming several things both related to production and marketing have been determined in advance regarding the type of commodity, quantity and quality of commodities, production technology, and the use of production inputs [8]. While marketing involves prices and guarantees of the core party in purchasing production output produced by farmers. In addition to guarantees for the purchase of products produced, the core parties generally provide supervision facilities, credit, production inputs, borrowing or leasing machinery, and other technical assistance / advice [9-11]. 
process was achieved through hermeneutic circle to understand how farmers involved in the program, interpreted the program including their own experiences and interactions with other parties.

\section{DISCUSSION}

In East Java, the contract farming model has been widely used by many processing industries and agribusiness companies to produce or obtain the raw material they need. Some examples that can be seen today such as in the dairy industry, PT Nestle has long entered into business contracts with dairy cooperatives in the region in the GKSI container (Indonesian Milk Cooperative Association). Another example is also found in tobacco farming where several agricultural cooperatives or farmer groups directly choose to seek their production in a written contract with several private companies. The same case can also be found in vegetable commodities to fulfill supermarket outlet orders. Production for several types of hybrid seeds such as maize, rice and horticultural crops carried out by large companies such as PT PIONEER, PT BISI and others are also obtained through contracts with farmer groups and cooperatives. Some other commodities needed by the industrial sector such as cotton, sugar cane and cocoa are also produced through contractual cooperation with local farmers.

Contract farming systems between farmers and agribusiness companies can be found in 25 locations / districts in East Java from a total of 38 districts / cities (Table 1). There are approximately 44 agribusiness companies operating in this region carrying out contract farming with local cooperatives or farmer groups to produce more than 28 types of agricultural commodities. type of hold-up is the refusal of commodities supplied under the pre-text of non-compliance with quality regulations companies might refuse to receive commodities as a strategy for transferring financial losses arising from an unexpected market to farmers [12].

In relation to the existing phenomenon, this study aimed at: (1) exploring the technical implementation of the contract farming partnership which had been done by farmers and their partner companies in East Java, and (2) identifying issues and benefits of partnership for both parties .

\section{RESEARCH DESIGN}

Research was conducted in several cities in East Java producing agricultural commodities under contract system with a number of major processing companies, such as PT. Nestle and PT. HM. Sampoerna. It adopted an interpretive research design, following a post-positivist paradigm. The analysis relied on primary data collection through interviewing local parties including farmers, chairmen of the farmers group, academicians and government agencies. The secondary data were collected through document study to examine the contract farming related policies as well as the archives owned by government agencies or other relevant resources. In the analysis, we specifically looked at the issues and perceived benefits of contract farming for farmers and their partner company. The data were analyzed using the key tenet of Martin Heidegger's interpretive phenomenology. The interpretive
TABLE I. DistribUtion OF CONTRACT FARMING AREAS IN EAST JAVA

\begin{tabular}{|c|c|c|}
\hline Commodity & Districts with Contract Farming & Total \\
\hline \multicolumn{3}{|c|}{ Crops } \\
\hline Rice & $\begin{array}{l}\text { Pasuruan, Malang, Gresik, Lamongan, } \\
\text { Magetan, Tulungagung, Ngawi, Blitar, } \\
\text { Tuban, Nganjuk, Banyuwangi, Sampang, } \\
\text { Pamekasan, Sumenep }\end{array}$ & 14 \\
\hline Corn & $\begin{array}{l}\text { Malang, Gresik, Probolinggo, Blitar, } \\
\text { Jember, Nganjuk }\end{array}$ & 6 \\
\hline Soy & Pasuruan, Jember, & 2 \\
\hline Cassava & Bondowoso & 1 \\
\hline \multicolumn{3}{|c|}{ Horticulture } \\
\hline Vegetables & $\begin{array}{l}\text { Pasuruan, Probolinggo, Kediri, Magetan, } \\
\text { Jember, Sampang, Malang, Batu }\end{array}$ & 8 \\
\hline Fruit & Pasuruan, Gresik, Pacitan, Trenggalek & 4 \\
\hline \multicolumn{3}{|c|}{ Industrial Crops } \\
\hline Sugarcane & Malang, Probolinggo, Kediri, Nganjuk & 3 \\
\hline Tobacco & Bondowoso, Jember, Lumajang & 2 \\
\hline Coconut & Jember & 1 \\
\hline Chocolate & Pacitan & 1 \\
\hline $\begin{array}{l}\text { Sengon \& } \\
\text { Bamboo }\end{array}$ & Bondowoso, Magetan & 1 \\
\hline \multicolumn{3}{|c|}{ Livestock } \\
\hline Dairy cows & Bojonegoro, Malang, Pasuruan, Blitar & 4 \\
\hline Chicken & Malang, Probolinggo & 2 \\
\hline Fishery & Kediri, Probolinggo, Banyuwangi, Blitar & 4 \\
\hline
\end{tabular}


TABLE II. BENEFITS OF CONTRACT FARMING

\section{A. Contract Farming Model}

There are many contract farming models in East Java, but in general the mechanism of commodity flow produced by farmers is divided into 3, namely (1) farmers directly contract with official representatives from contract companies; (2) farmers enter into contracts with intermediary traders, then they deposit it to the official representative of the company and (3) farmers enter into contracts with collectors but their harvest will be collected by intermediary traders then they hand it over to collectors then to the contracting company. These three models have different implications for commodity prices produced by farmers. The longer the supply chain, the smaller the contract price will be. The party that benefits the most and plays the price most often is the intermediary trader. They are the ones who usually play the price by floating the method of determining 'grading'. Information related to 'grading' is only owned by intermediary traders and collectors. This condition causes farmers to be reluctant to enter into contractual cooperation. The following is a description of the contractual cooperation that has been carried out by several agribusiness companies in East Java.

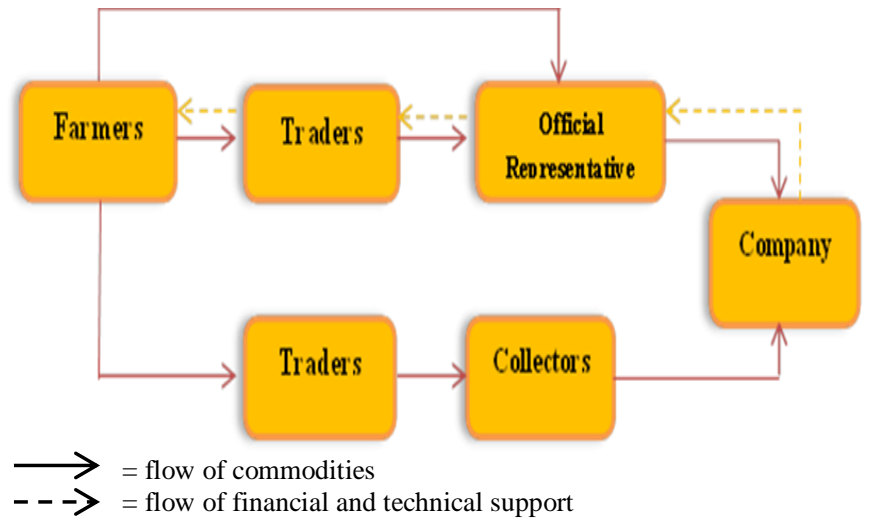

Fig. 1. Contract farming model.

As shown in the above figure, farmers or groups of farmers generally enter into indirect partnership contracts with partner companies through intermediaries, can be intermediary traders or collectors. In a contract, the company usually guarantees the absorption of commodities produced by farmers at an agreed price as long as the commodity meets the quality standards that have been determined before the planting season. In return, farmers receive financial assistance in the form of access to capital, both financing facilities and infrastructure or inputs and technical assistance in the form of good agricultural practices.

\section{B. Benefits of Contract Farming}

The benefits derived from contract farming are summarized in the following table:

\begin{tabular}{|c|c|}
\hline PARTY & BENEFITS \\
\hline FAMERS & $\begin{array}{l}\text { - Market Access } \\
\text { Contract farming provides certainty for marketing } \\
\text { farmers of the commodities they produce. With this } \\
\text { market guarantee, farmers will get a certain and stable } \\
\text { income. } \\
\text { - Income increases } \\
\text { Contract farming helps farmers to estimate how much } \\
\text { income they will earn, making it easier for them to make } \\
\text { financial planning and the next production schedule. } \\
\text { - Reducing the risk of price fluctuations } \\
\text { Contract farming will reduce the risk of loss that might } \\
\text { occur because there is a decrease in the price of } \\
\text { commodities sold. } \\
\text { - Access credit } \\
\text { Contract farming makes it easy for farmers to get credit } \\
\text { from banks or financial institutions through the role of } \\
\text { partner companies. The partner company helps extract } \\
\text { the debts that must be paid by the farmers from the } \\
\text { payment of the harvest. } \\
\text { - Input Access } \\
\text { Farmers will find it easy to get inputs on time because in } \\
\text { agriculture input contracts are provided by partner } \\
\text { companies. } \\
\text { - Reducing production risk } \\
\text { Contract farming facilitates risk mitigation if production } \\
\text { fails due to uncontrolled conditions (bad weather or } \\
\text { disease / pests) } \\
\text { - Introduction of high value plants } \\
\text { Contract farming will usually introduce superior varieties } \\
\text { of plants or new technologies to increase production not } \\
\text { found in traditional agriculture. }\end{array}$ \\
\hline $\begin{array}{l}\text { PARTNER } \\
\text { COMPANY }\end{array}$ & $\begin{array}{l}\text { - Sustainable supply of raw material } \\
\text { With contract farming, the company is guaranteed the } \\
\text { supply of raw materials in accordance with the required } \\
\text { quality and quantity standards } \\
\text { - Reduced transaction cost } \\
\text { With contract farming, the company does not need to } \\
\text { search for and buy raw material needs in the market, } \\
\text { thereby reducing the transaction costs } \\
\text { - Access to cheap labor } \\
\text { With contract farming, companies do not need to pay } \\
\text { workers to manage their farms because everything is } \\
\text { done by contract farmers } \\
\text { - Land } \\
\text { With contract farming, the company does not need to } \\
\text { invest in land thereby saving the company's investment } \\
\text { costs. }\end{array}$ \\
\hline
\end{tabular}

\section{Problems in Agriculture Contracts}

An assessment of the contract farming system generally shows positive results where smallholders benefit in the form of increased income, access to marketing, access to credit and technology, increased ability to manage risk, employment opportunities for indirect family members, empowerment of women and development successful business culture. Nevertheless, evidence is also found that contractual farming has negative consequences for farmers. Some findings in the field show a number of important notes that need to get the attention of all parties, especially the government, of which can be stated in the explanation below:

1) Production input and output conditions: The principle of the contract farming relationship is the principle of exchange, where farmers are obliged to provide land and labor to produce commodities needed by the partner company, while 
price, and these are decided by the partner company. To be able to fulfill all the agreements made, the farmers are required to manage their agriculture intensively. For farmers, intensive management means the loss of opportunities to generate other income needed to survive. This monoculture technology limits farmers if it cannot be said to completely eliminate the opportunity for farmers to look for other income opportunities and 'leave' their obligation to manage their plantations.

On the other hand, from the point of view of companies, contract farming is not without difficulty. Farmers may, on occasion, sell their outputs to outsiders even though they have been produced using inputs supplied by the company. Farmers' default contract will increase with an increase in the number of willing buyers. As new markets emerge and rival buyers offer competitive rates, farmers are given the incentive to break their contracts, frequently refusing to repay input loans to the contractor. In this case, an effective legal system and collateral held by small farms are needed to eliminate risks for partner company. Government support is another important requirement. Contracts need to be backed up by legislation and a reliable legal system. Existing legislation may have to be revised to ensure that it does not hinder the growth of agribusiness and contract farming.

Basically, the contract farming system is a risk transfer mechanism. The partnership is carried out to reduce risk. Thus contract farming can reduce the risk of price fluctuations if buying raw materials on the open market. By carrying out contract farming, the company has certainty about the price of raw materials needed. They also get other benefits such as do not have to invest quite expensive investments in land and manage a very large farm. While for the farmers, the contract farming system will overcome their common problems they face in the process of transferring the risk of uncertainty on price and marketing their products. However, tfracighis system also invites another new risk for them that is monopsony market. This monopsony market will lead to new farmers' dependence on companies. This situation will get worse if farmers do not have the opportunity to diversify their business, for example to obtain income from non-agricultural activities or produce several types of plants at the same time. Business diversification will reduce barriers for farmers to get out of the contract farming relationship if farmers do not want it, while reducing the risk of dependency on the company.

From the company side, there are generally not facing many obstacles in diversifying suppliers to reduce the risk of dependency on farmers. Sometimes companies own their own land and employ workers to produce the same commodities that farmers grow so that farmers' commodities are only a complement to the products they produce. Companies also often combine several supply methods at once, including buying raw materials from the free market. The following table presents several ways of risk transfer in contract farming and strategies to reduce the risk of farmers' dependence on companies and vice versa. in the form of fertilizer, seeds, and various assistance and other technical support from partner companies. In return, partner companies want quality and quantity standards to be met, when they must be produced and harvested, and at what 
highly experienced company management and staff and also government officers. Our sincere appreciation goes also to the Ministry of Science, Technology and Higher Education of Indonesia, which has helped us to fund this research.

\section{REFERENCES}

[1] A. Daryanto,"Peningkatan Nilai Tambah Industri Perunggasan Melalui Supply Chain Management," [Online]. Retrieved from http://ariefdaryanto.wordpress.com/2007/09/23/peningkatan-nilaitambah-industriperunggasan-melalui-supply-chain-management/

[2] T.T.H. Thambunan, "Identifying Business Models Adopted by FDI in Agriculture in Indonesia," Journal of Economics and Development Studies, vol. 2, no. 1, 2014.

In order to improve the competitiveness and bargaining power of farmers towards partner companies, the government, as a facilitator, needs to actively bridge unequal communication between farmers and companies through policies aimed at regulating and facilitating the program for increased economic empowerment of farmers. The policies may include: 1). Legalizing the benchmarking of agriculture commodity's prices so that farmers can assess the fair prices of their commodities when selling them to the warehouse. (2). Standardization of commodity's quality policy A, B, and C as to the degree that the price has so far been determined solely and subjectively by the purchaser.

This study also concluded that social capital in the form of trust, reciprocity and social networks is very influential on the success of the contract farming program. Therefore, this contract farming system must be seen as a form of partnership between agribusiness companies and farmers, whose success is largely determined by the long-term commitment of both parties. In addition, the existence of transparency, guaranteed production and prices, equitable sharing of risks, good communication and mutual control over the quality and level of production efficiency among the actors is needed in this collaboration. Thus, the most important essence of contract farming is sharing of resources, mutual support and mutual benefit.

\section{ACKNOWLEDGMENT}

We especially enjoyed the encouraging discussions we had with all the partners involved in this research project. The discussions provided us with valuable insights into the nature of the contract farming partnership in East Java. It was a real pleasure and a great help for us to exchange ideas and learn
[3] F. Rustiani, H. Sjaifudian, and R. Gunawan, Mengenal Usaha Pertanian Kontrak (Contract Farming). Bandung: Yayasan AKATIGA, XIV, 1997.

[4] K.B. Andri, "Melihat Potensi dan Sistem Usaha Tani Kontrak, Inovasi Online, Edisi 7/XVIII/Juni," [Online]. Retrieved from http://io.ppi-jepang.org

[5] S. Sivramkrishna and A. Jyotishi, "Monopsonistic exploitation in contract farming: Articulating a strategy for grower cooperation," Journal of International Development, vol. 20, pp. 280-296, 2008.

[6] G. Alvarez and O. von Hagen, "The Impacts of Private Standards on Producers in Developing Countries: Literature Review Series on the Impacts of Private Standards, Part II (December 1, 2011)," [Online]. Retrieved from https://ssrn.com/abstract=2184273

[7] K.D.S. Susilowati, A. Rachmi, and N.I. Riwajanti, “Analysis of Contract Farming Partnership for Sustainable Supply of Tobacco (a Case Study on the Integrated Production System Program of PT. HM Sampoerna Tbk.- Indonesia)," International Journal of Engineering and Technology, vol. 7, no. 415, pp. 219-223, 2018.

[8] S. Setboonsarng, Global Partnership in Poverty Reduction: Contract Farming and Regional Cooperation. ADBI Discussion Paper 89. Tokyo: Asian Development Bank Institute, 2008.

[9] M. Will, "Contract farming handbook - A practical guide for linking BMZ - Federal Ministry for Economic Cooperation and Development, GIZ, Deutch," 2013.

[10] C.A. Da Silva and M. Rankin, Contract Farming For Inclusive Market Access. Rome: FAO Rural Infrastructure and Agro Industries Division, 2013.

[11] C. Eaton and A.W. Shepherd, Contract Farming: Partnership for Growth. Roma: Food and Agrilculture Organization Services Bulletin No. 145, 2001.

[12] C.A. Da Silva, The Growing Role of Contract Farming in Agrii-Food System Development, Drivers, Theory and Practice. Rome: FAO, 2005.

[13] A..A Saptana and H. Mayrowani, "Sunarsih. 2006. Analisis Kelembagaan Kemitraan Rantai Pasok Komoditas Hortikultura," Bogor: Pusat Analisis Sosial Ekonomi dan Kebijakan Pertanian Departemen Pertanian, 2006. small-scale producers and buyers through business model innovation - 